\title{
Seventh Iowa Volunteers in Civil War Gave Valiant Service
}

\author{
By C. C. Carpenter and Geo. W. Crossley
}

Perhaps no Iowa regiment engaging in the battles of the Civil war bore more of the severe fighting in which the Northern troops engaged in the western battle area than the Seventh Iowa regiment of volunteer infantry. The record of this distinguished body of Iowa men is one of great credit, bravery and sacrifice.

Under "proclamation of President Lincoln, bearing date May 3, 1861, the companies composing this regiment were ordered to rendezvous at Burlington, Iowa, and were mustered into the service of the United States by Lieut. Alexander Chambers, United States Army, on dates ranging from July 23 to August 2, 1861. Its first field officers were Col. Jacob G. Lauman, Lieut. Col. Augustus Wentz and Maj. Elliott W. Rice.

During its period in service the regiment had three colonels, the commanding officer following Colonel Lauman being James C. Parrott, who previously upon induction had been captain of Company $\mathrm{E}$ of the regiment. The third colonel commanding the regiment was Elliott W. Rice, who at time of induction had held the rank of major.

Like its predecessors the Seventh had but a short stay in its camp at rendezvous, for, on the 6th day of August, only four days after its last company had been mustered, the regiment was ordered to St. Louis, and embarked on the steamer Jennie Whipple, with its camp equipage and baggage. It arrived in St. Louis on the morning of August 8th and marched to the government arsenal, where it was armed, the two flanking companies with Springfield rifles, and the other eight companies with improved Springfield muskets.

The regiment was in Jefferson Barracks for a short time, then went to Pilot Knob, thence to Ironton, where 
it remained in camp about two weeks, during which time it had the first opportunity to learn the manual of arms, and was instructed in some of the simpler movements of the company, battalion and regimental drill. About the 1st of September it started on its first campaign with a division composed of six regiments, under the command of Brig. Gen. B. M. Prentiss.

Jackson and Cape Girardeau, Mo., were occupied, and from the latter place the regiment proceeded by steamboat to Cairo, Illinois, and immediately after its arrival there was sent to occupy the position afterwards known as Fort. Holt, Kentucky. It remained there but two weeks, and then moved to a point about eight miles from Columbus, where the Rebels had constructed a strong fort. From this point-named Camp Crittenden-the main body of the regiment moved to Fort Jefferson on the Mississippi river, but left a strong picket guard at Camp Crittenden, where one man was wounded in a skirmish with the enemy. Leaving Fort Jefferson, the regiment proceeded to Norfolk and Bird's Point and, at the latter point, remained for some weeks doing picket and guard duty. November 6th, the regiment proceeded on board transports to a point on the Missouri shore about three miles above Belmont, where eight of its ten companies disembarked, leaving two companies to guard the transports.

\section{First Battle At Belmont}

Joining the Twenty-second Illinois regiment, the Seventh Iowa advanced, on the left of the Union line, against the enemy. The official report of Colonel Lauman related details of the engagement and how bravely this regiment fought in this their first battle. After sketching preliminary movements, how the battle was waged was described in the colonel's report in part as follows:

From this time, about 11 o'clock, we fought the Rebels slowly but steadily, driving them before us at every volley. Our advance at this point was slow in consequence of the obstructions in our way, caused by fallen timber and under- 
brush, but we crept under and over it, at times lying down to let the fire of the artillery and musketry pass over us, and then up and onward again, until we arrived at the field to the left of the Rebel camp. Here we were joined by our skirmishers, who had succeeded, after a severe struggle, in driving back the enemy.

Forming our line immediately; we poured volley after volley on the retiring foe across the field in front; and on the battery which was stationed at the head of the encampment on our right. Our fire was so hot the guns were soon abandoned, the enemy, about 800 , flying, across the field in the greatest consternation. By a flank movement to the right, I brought my men into the open space in front of the battery, which was immediately taken possession of, I believe by Lieutenant DeHeus'.Company A, whose flag was soon seen flying from one of the captured pieces. We were now immediately in rear of the encampment, and were joined by a portion of Colonel Dougherty's Twenty-second Illinois regiment.

The Rebels kept up a sharp and galling fire upon us, but a few well directed volleys induced them to abandon their camp suddenly. It. was here, while the firing was heaviest, that First Sergeant Walker, of Company I, seized the regimental colors and bore them aloft and in front of the regimental line, directing the attention of the boys to a fine, large flag, floating over the encampment, decorated on one side with twelve stars, and on the other with the "Harp of Erin" on a green silk ground; they, with loud huzzas, went forward and secured the flag.

It was in making this charge that my horse was shot. I followed the regiment on foot until we reached the lower end of the encampment, when I was supplied with another horse, which had just been captured by one of the men, when, immediately ordering another charge, we drove all the remiaining Rebels over the bank of the river (at this point some twelve feet high), and dashed up the river road until we arrived at the log house which constitutes the "City of Belmont." At this place there was considerable random firing, the Rebels firing from the cover of trees and the bank of the river, and it was here, while giving Captain Parrott, of Company E, orders to "bring off two field pieces which had been abandoned by the Rebels, or to throw them into the river," so as to render them useless against us, that I received a ball through my left thigh, which for a time disabled me. I was assisted by Captain Parrott to the rear of the tents, where I remained but a short time, as, one of the guns of Captain Taylor's battery coming along, they placed me on it and took me to the rear of the encampment. In the meantime, our men had 
received orders to burn and destroy the camp and property which had fallen into our hands, and in a very short time the destruction was complete.

The Rebels had, however, not been idle. Having several large steamers at Columbus, they were loaded down with fresh troops, which were thrown between us and our place of debarkation, so as, in a measure, to cut off our retreat. Those of them also who had been driven from their guns in the early part of the fight, seeing us falling back towards our boats, took fresh courage and commenced closing in. on us, and as all the Illinois troops had left, or were leaving, except Colonel Dougherty's regiment, we were in danger of being surrounded and cut off. I was apprised of this state of affairs by Colonel Dougherty, to whose bravery I desire to-bear testimony, and who lost a limb in his efforts to bring off safely the rear of his brigade, as well as to that of his noble regiment, which fought side by side with us on that memorable day.

I immediately gave orders to my regiment to retire, myself leading the way, but, by this time, we were subjected to an enfilading fire which caused us heavy losses; the men behaved in the most gallant manner, deliberately loading and firing as they retired, and although every other man was either killed or wounded, they scarcely accelerated their step, but coolly and deliberately made their way to the boat. It was after the retreat had commenced that Lieutenant Colonel Wentz was killed. He-died on the field of battle, like a true soldier; he was a truly brave man and did his duty well and nobly. Lieutenant Dodge, of Company $B$, was killed, and Lieutenant Gardner, who commanded Company I, and Lieutenant Ream, of Company C, mortally wounded.

Among my officers, more or less severely wounded, you will find the names of Major Rice, Captains Harper, Parrott, Kittredge and Gardner, and First Lieutenant De Heus (who commanded Company A) of whose bravery I desire to speak in the most emphatic manner. I desire also to direct your attention to Captain Crabb, who was taken prisioner, and who behaved in the bravest manner. But I might go on this way and name nearly every man in the regiment, for they all behaved like heroes, but there are one or two more I feel it my duty to name as deserving special mention: Lieutenant Bowler, Adjutant of the regiment, and Lieutenant Estle, whose conduct was worthy of all praise, and Private Lawrence A. Gregg, whose thigh was broken, and who was left on the field; he was taken prisoner, and his leg amputated, but he died the same day, telling his captors with his dying breath that, if he ever recovered, so as to be able to move, he would shoulder his musket again in his country's cause. 
My regiment's entire loss in killed, wounded, prisoners and missing, out of an aggregate of somewhat over 400 engaged, is as follows: Killed 51 , died of wounds 3 , missing 10 , prisoners 39 , wounded 124 , total 227.

\section{General Grant's Praise}

In his official report of the battle, General Grant says: "The Seventh Iowa behaved with great gallantry, and suffered more severely than any other of the troops." The day after the battle, the General issued the following brief but characteristic address:

Headquarters District Southeast Missouri, Cairo, Nov. 8, 1861

The General commanding this military district returns his thanks to the troops under his command at the battle of Belmont on yesterday. It has been his fortune to have been in all the battles fought in Mexico by Generals Scott and Taylor, save Buena Vista, and he never saw one more hotly contested or where troops behaved with more gallantry. Such courage will insure victory wherever our flag may be borne and protected by such a class of men. To the brave men who fell, the sympathy of the country is due, and will be manifested in a manner unmistakable.

\section{U. S. GRANT}

\section{Brigadier General Commanding}

General Grant reported the total loss in his command at four hundred and eighty-five. It will thus be seen that the Seventh Iowa sustained a loss of nearly one-half that of the two brigades engaged in the battle of Belmont. It seems almost incredible that these untrained troops, fighting their first battle, and led by regimental and company officers without military training or experience, should have acquitted themselves when under fire for the first time as well as in any of the subsequent battles in which they were engaged, and in all of which they nobly maintained the honor of the State which sent them into the field.

Another notable feature of the battle of Belmont was the fact that it was the first in which General Grant had command of the Union troops, and his first opportunity to demonstrate his fitness and capacity to command. The Seventh Iowa infantry had a long 
and most honorable record of service, and greatly distinguished itself upon other battlefields.

The following extract from the report of Lieut. Col. James C. Parrott will show how the regiment again performed the duty assigned to it, in the reduction and capture of Fort Donelson, an important stronghold of the enemy:

The Second Iowa was given the post of honor, in leading the charge, supported by the balance of the brigade. The Seventh Iowa moved up to the works in fine style, entered the sally-port, and gained, with Second Iowa, a position inside the Rebel works. We were then ordered by the brave, gallant and lamented General Smith to fall back, and take shelter on the outside of the Rebel works.

On the holy Sabbath morning, February 16th, as the day dawned, in the dim distance could be seen the white flag, which in plain language told us all that the strife for the mastery of Fort Donelson had ended, and in a short time the whole column of our wing was marching into the fort, amid loud huzzas, the beating of drums, and the shrill music of fifes, and the time honored stars and stripes waving over us. So.fell Fort Donelson, and the Seventh Iowa claims her meed of praise.

The loss of the regiment in this engagement was two killed and thirty-seven wounded. Its relatively small loss, as compared with the Second Iowa, is accounted for by the fact that the Second led in the assault, while the Seventh was with the supporting column, and therefore was not as greatly exposed to the heaviest fire of the enemy's musketry and artillery, but the regiment performed its full duty in the position in which it was placed.

After the fall of Donelson, the regiment remained in the fort some three weeks, quartered in the rude cabins which the Rebels had erected. It then marched to Metal Landing on the Tennessee, and, after about a week there, went on board the steamer White Cloud, and proceeded to Pittsburg Landing, where it went into camp. On the morning of April 6, 1862, the regiment went into action in what has been known generally as the battle of Shiloh, under command of Lieut. Col. J. C. Parrott, and in the two days' progress of that great battle again nobly maintained the honor of its state. 


\section{Desperate Fighting At Shuloh}

On the second day, the gallant Lieutenant Colonel Parrott was so prostrated by illness and exposure that he was compelled to relinquish the command to $\mathrm{Maj}$. E. W: Rice, of whom he says, in his official report "I knew it was placed in good hands, and from him I was proud to learn that it did its duty unflinchingly."

On the first day of the battle of Shiloh, Iowa troops. were conspicuous in this last line of resistance, where the fighting continued until after dark, and which resulted in checking the advance of the enemy, and retrieving the disasters of that day. At the close of this battle, the Seventh Iowa had been in the service but about eight months, had participated in three important battles, with an aggregate loss of 300 ' of the 884 officers and men with which it had left the State; and yet it had not completed one-third of its long and arduous term of service: After the battle of Shiloh, the regiment remained in camp until the Union army again assumed the offensive and the advance upon Corinth began, which resulted in the siege of the stronghold, and its evacuation by the enemy on the 30th of May, 1862.

In all the operations of the brigade and division to which it was attached during this advance and siege, the Seventh Iowa had its full share, on the skirmish and picket line during the advance, in trenches during the siege, and in the pursuit of the enemy after the evacuation. The pursuit ended at Boonville, Mississippi, the enemy having made good his retreat, and the Seventh, with its brigade and division, returned to Corinth, going into camp about two miles southeast of that place, where it remained for the balance of the summer, doing picket and camp guard duty, and perfecting itself in company and battalion drill and manual of arms. In his official report Lieutenant Colonel Parrott says, "On the 15th of September, we were ordered to Iuka; arrived there on the 17th, and, as stated in General Grant's order No. 1, our division 
deserves as much credit and praise as the troops who were actually engaged."

\section{Men and Officers Fought Nobly}

From Iuka, the regiment returned to Camp Montgomery, where it remained until the $3 \mathrm{~d}$ of October, when it was again called into action, to meet the forces of Van Dorn and Price who were advancing to the attack of the Union forces in and around Corinth. . Maj. Elliott W. Rice, having been promoted to the rank of Colonel, was now in command of the regiment. His official report of the conduct of the Seventh Iowa in the hard fought battle of Corinth, October 3 and 4, 1862, is quoted from in part:

.. . The enemy's battery was placed directly in front of my command, and a most terrific cannonading ensued. $\mathrm{My}$ men held this position firmly and unflinchingly for one hour and a quarter, exposed to a murderous fire of shell and canister. Our battery, having exhausted its ammunition, retired and the Rebel infantry advanced in strong force. My men were kept concealed until the enemy advanced within short range, when I opened fire upon them from my whole line, and, for a time, held them in check. They soon rallied, and I was ordered to take a position further in the rear. The enemy moved on, our whole brigade made a sudden charge, and the enemy was again checked, thrown into some confusion, and repulsed. This gave an opportunity to take a more favorable position, and another line was formed between the white house and Battery Robinett, at a point where two howitzers were posted. This position was held until most of the wounded has passed to the rear, and my ammunition was entirely exhausted, when, by order of General Davies, my command was placed to support a battery on the left of Battery Robinett. Gaining this position, I immediately supplied my men with forty rounds of ammunition. Night coming on, the battle of the $3 \mathrm{~d}$ was ended, and I had lost many noble men. At 10 p.m. I received Colonel Sweeny's order to proceed with my command to a position east of Corinth, and at 1 o'clock the following morning my regiment was moved to a line north of Corinth, when a line of battle was formed fronting west, my position in the brigade being still on the left.

At 3:30 o'clock, the enemy's artillery commenced shelling the town, and about 10 o'clock it was ordered to proceed with my command to the front and deploy it as skirmishers. This 
deployment was made and two center companies held as a reserve. After advancing a short distance, I ascertained that the enemy was crossing the railroad in force to a position on the right. I immediately dispatched Lieutenant Colonel Parrott to General Davies with this information, who at once ordered me to return to my former position. I had but gained it for a short time, when the enemy appeared and charged on the battery defended by the brigade on the right of the First.

The brigade on my left was attacked at the same time. I opened a vigorous oblique fire on the enemy charging the battery, and continued it until General Rosecrans ordered me to cease firing. Soon the brigade on my left fell back. The enemy gaining position on my left flank, I was ordered to retire a short distance. I halted my command about fifty yards in the rear. An advance was soon ordered, and I immediately gained the position just abandoned, and the enemy was driven into the woods. They made another attempt, directly in front of my regiment, to charge the battery. My men held their position firmly, checking the enemy, who took refuge from the storm of bullets, which was rained upon them, in the abatis.

The Seventeenth Iowa coming upon my left flank, I advanced rapidly on the Rebel position, when they broke and ran in great confusion. My command had fired the whole of the sixty rounds of cartridges with which it had been supplied in the morning, but was immediately supplied, without leaving the field, by my excellent quartermaster, Lieutenant Forsha, who, regardless of personal safety, was ever ready to supply my command with ammunition, even in the heat of battle. I remained in this position during the balance of the day, and at night bivouacked on the battlefield.

. . . I must make special mention of Lieutenant Colonel Parrott, who cheered and encouraged the men, and performed his duty with great bravery. It is with pleasure I make favorable mention of almost all my officers who were engaged in the two days' battle. Major McMullin did efficient service until he was wounded and disabled on the evening of the $3 \mathrm{~d}$. Captain Conn, although wounded, remained with his command through both days' battle. Captain Hedges and Mahon, left in camp sick, left their beds and came on the battlefield on Saturday, and did excellent service. Their companies were well commanded on Friday by Lieutenants Dillon and Sargeant. Lieutenant Gale displayed great galiantry, and was very severely wounded in the battle of the 4th, after which the company was bravely led by Lieutenant Morrison. Captains Irvin and Reiniger also performed their duties nobly. 
I must also mention Lieutenants Hope, Loughridge, Irvin, McCormick, Bennett and Bess.

Captain Smith, who was killed in the last hour of the battle of the 4th, was one of the most promising young officers of the service. He was brave, cool and deliberate in battle, and very efficient in all his duties. Color Sergeant Alec Field was wounded in the battle of the 3d. Afterward the colors were borne by $\mathrm{Wm}$. Akers of Company G, who was also wounded. They were then carried by George Craig, of Company $B$, all the color guard, with the exception of one, being either killed or wounded. Sergeant Major Cameron, severely wounded, must not escape favorable mention for his bravery. While it is a pleasure to record the noble and heroic conduct of so many of my officers and men, we mourn the loss of our gallant dead, and sympathize deeply with the unfortunate wounded. More than one-third of those taken into action are wounded, or lie dead beneath the battlefield.

The regiment's loss in the battle of Corinth was 122, making a total loss in battle, up to and including the 4 th of October, 1862, of 422 officers and men. When the long list of names of those who had died from disease, and of those who had been discharged on account of disability caused by sickness, is added to the actual casualties in battle, the tremendous aggregate loss of this regiment, with but little more than fourteen months' record of service, almost equaled the number first mustered into the service at Burlington, while its original term of service was not yet half completed. Of course, many recruits had been received, and many of the sick and wounded had, from time to time, sufficiently recovered to be able to return to the regiment, and thus its decimated ranks were replenished, but never again did it number half the maximum of a full regiment of officers and men able for duty at any one time.

\section{A Merited Furlough For Men}

After being stationed at Rienzi, Mississippi, and at other points contiguous to Corinth and with occasional engagements, the regiment was ordered to Bethel, Tennessee, where it remained some time, later to Moscow and La Grange, Tennessee, and participated in an expedition to Holly Springs, Mississippi. In Decem- 
ber, 1863, having reached Iuka, three-fourths of the men were re-enlisted and given a furlough of thirty days on arriving at Keokuk, and thence to their homes.

Upon reassembling in January, 1864, at Keokuk, the regiment and recruits went to Nashville, via Cairo by. boat to engage in the memorable Atlanta campaign, in which it bore a conspicuous part as shown by official reports, meeting the enemy at Lay's Ferry, from the 1st of September being constantly at the front. Lieutenant Colonel - Parrott, who had partially recovered and was again in command, says in his official report: "At Rome Cross Roads, Dallas, New Hope' Church, Big Shanty, Kenesaw Mountain, Nick-a-Jack Creek, and in close proximity to Atlanta, the Seventh. Iowa bore an honorable part. - On July 22d, when the lamented McPherson fell, the gallant old Seventh was an active participant in the bloody fray, and added new laurels to her former bright record."

The report concludes as follows: "I am proud to say that the conduct of both officers and enlisted men of the regiment, in the arduous campaign just closed, has been all that could be desired. Every fatigue, however severe, has been cheerfully borne, and they have been always ready for the post of danger. Whether on weary marches, many of them performed at night, over difficult roads, or working in the trenches before Atlanta, under the fire of the enemy's sharpshooters and artillery, or standing shoulder to shoulder on the battlefield, they have done their whole duty."

The regiment next took an active part in the operations which resulted in the evacuation of Atlanta. It then proceeded to Rome, Georgia, thence to Allatonna.

On the 11th of November the Seventh Iowa regiment took up the march through the heart of Georgia and entered the city of-Savannah on December 21, 1864. On the 28th day of January, 1865, the regiment. left Savannah to enter upon its last great campaign, through the Carolinas, which practically ended in the last days of March 1865 . In his official report, dated 
at Goldsboro, North Carolina, March 27, 1865, Lieutenant Colonel Parrott describes the movements and operations of his regiment with great particularity; showing the almost incredible hardships encountered in wading through swamps, often waist deep, marching over wretched and nearly impassable roads, often drenched by heavy rains, and, added to these hardships;" skirmishing almost daily with the enemy, now rendered desperate by the certainty of the complete triumph of the armies of the Union.

Upon reaching Goldsboro, the Seventh regiment had covered a distance of 480 miles from their starting point on the southern sea coast, but, after a season of rest, again started north, cheered by the thought that the cause for which they had suffered and endured such great hardships was at last triumphant, and the remainder of the march to Washington would be made with comparative ease.

At last the goal was reached. On that memorable 24th day of May, 1865, the Seventh Iowa infantry proudly wheeled into its place in line with the grand army which marched down that broad avenue of the $\mathrm{Na}$ tion's Capital; and passed in review for the last time. Its days of marching and fighting were over:. A little later on, it was sent to Louisville, Kentucky, where, on the 12th day of July, 1865, it was mustered out of service, was then sent to Davenport, Iowa; where final payment to men and officers was made, the regiment disbanded, and the men furnished with transportation to their homes.

\section{Book Gift Started Library}

The first library in the United States began in 1638, when John Harvard gave 400 books to the university named for him. 
Copyright of Annals of Iowa is the property of State of Iowa, by \& through the State Historical Society of Iowa and its content may not be copied or emailed to multiple sites or posted to a listserv without the copyright holder's express written permission. However, users may print, download, or email articles for individual use. 